\title{
Nutrient composition and in vitro ruminal fermentation of tropical legume mixtures with contrasting tannin contents
}

\author{
C.D. Stürm ${ }^{a}$, T.T. Tiemann ${ }^{\mathrm{a}, \mathrm{b}}$, C.E. Lascano ${ }^{\mathrm{b}}$, \\ M. Kreuzer ${ }^{\mathrm{a}}$, H.D. Hess ${ }^{\mathrm{a}, *}$ \\ a Institute of Animal Science, Animal Nutrition, Swiss Federal Institute of Technology (ETH), \\ CH-8092 Zurich, Switzerland \\ b Tropical Grass and Legume Project, CIAT, Cali, Colombia
}

Received 16 June 2006; received in revised form 1 November 2006; accepted 7 November 2006

\begin{abstract}
Various combinations of a low-tannin herbaceous legume (Vigna unguiculata) and foliage of tanniniferous shrub legumes (Calliandra calothyrsus, Flemingia macrophylla and Leucaena leucocephala) or a low-tannin shrub legume (Cratylia argentea), all mixed together with a low-quality tropical grass (Brachiaria humidicola), were tested in vitro for differences in the effects on ruminal fermentation. Two experiments with the gas transducer technique were carried out, where each forage mixture was tested either with or without polyethylene glycol in order to be able to identify tanninrelated effects $(n=3)$. In Experiment 1 , a stepwise replacement of $V$. unguiculata by $C$. calothyrsus $(5: 0,4: 1,3: 2,2: 3,1: 4,0: 5)$ at a legume proportion of $1 / 3$ or $2 / 3$ in the mixture was evaluated. Together with two grass-alone and four pure legume treatments this added up to 30 treatments. In Experiment $2, V$. unguiculata was gradually replaced by each of the four shrub legumes $(3: 0,2: 1,1: 2,0: 3)$ in grass-legume ratios of 2:1, adding up, together with two grass-alone treatments, to 28 treatments.
\end{abstract}

Abbreviations: ADF, acid detergent fiber; CP, crude protein; CT, condensed tannins; DM, dry matter; IVDMD, in vitro dry matter degradability; Lignin (sa), acid detergent lignin; NDF, neutral detergent fiber; OM, organic matter; PEG, polyethylene glycol; SEM, standard error of mean; UDCP, apparently undegraded crude protein; VFA, volatile fatty acid

* Corresponding author. Present address: Agroscope Liebefeld-Posieux, Research Station for Animal Production and Dairy Products (ALP), Tioleyre 4, CH-1725 Posieux, Switzerland. Tel.: +41 2640772 75;

fax: +4126407 7300 .

E-mail address: dieter.hess@alp.admin.ch (H.D. Hess).

0377-8401/\$ - see front matter (C) 2006 Elsevier B.V. All rights reserved. doi:10.1016/j.anifeedsci.2006.11.008

Please cite this article in press as: Stürm, C.D. et al., Nutrient composition and in vitro ruminal fermentation of tropical legume mixtures with contrasting tannin contents, Anim. Feed Sci. Technol. (2006), doi:10.1016/j.anifeedsci.2006.11.008 
When added alone, $V$. unguiculata resulted in high fermentative activity as measured by gas production and kinetics as well as low proportion of undegraded crude protein. When $V$. unguiculata was replaced by the low-tannin $C$. argentea in Experiment 2, there was no noticeable difference $(\mathrm{P}>0.05)$ in fermentative activity. In both experiments, the effect of the substitution of $V$. unguiculata by tanniniferous shrub legumes resulted in a declining gas production and an increasing proportion of undegraded crude protein $(\mathrm{P}<0.001)$. However, the extent of these changes depended on the level of replacement and the shrub legume species $(\mathrm{P}<0.001)$. The results of Experiment 2 illustrate that this was the consequence not only of different tannin contents (less adverse effects with L. leucocephala than with $C$. calothyrsus) but also differences in the chemical properties of the tannins present in these shrub legume species (much less adverse effects with L. leucocephala than with F. macrophylla despite similar tannin contents). Furthermore these results indicate that, once the extent of the effects of a tanniniferous legume is known, one may calculate the maximal level of replacement of a lowtannin legume in a grass diet possible without negative effects on ruminal fermentation. This allows to improve dry season grass-based diets with as few as possible of the expensive and less well growing low-tannin legume.

(c) 2006 Elsevier B.V. All rights reserved.

Keywords: Calliandra calothyrsus; Cratylia argentea; Flemingia macrophylla; Leucaena leucocephala; Tannin; Ruminal fermentation

\section{Introduction}

There is a rapidly increasing demand for products of animal origin in tropical countries. Ruminants can play an important role for meeting this demand and for income generation and poverty alleviation in rural and peri-urban areas (Delgado et al., 1999). However, productivity of ruminants in tropical smallholder farming systems faces serious constraints, in particular the poor availability and low-quality of feed in the dry season. Often the most limiting nutrient is protein (Minson, 1990). Therefore, leguminous fodder trees and shrubs (called shrubs further on) appear to have a great potential as supplement (Norton, 2000). Some shrub legumes show good agronomic performance even in the dry season and on acidic, low-fertility soils, presumably because of their deep root systems (Paterson et al., 1998). However, the feeding value of many of these legumes is low due to their typically high concentration of condensed tannins (Barahona et al., 2003). Condensed tannins (CT) are phenolic compounds that form complexes particularly with proteins and thus may act anti-nutritional at higher concentrations $(>50 \mathrm{~g} / \mathrm{kg}$ plant $\mathrm{DM})$ and reduce voluntary feed intake (Barahona et al., 1997). In contrast, dietary contents of $<50 \mathrm{~g} / \mathrm{kg}$ DM could be helpful in terms of metabolic protein utilisation due to a reduced protein degradation in the rumen and a increased flow of undegraded intake protein to the lower gut (e.g. Waghorn et al., 1987; Wang et al., 1994; Min et al., 2003). The extent to which protein-tannin complexes are released in the lower gut and can contribute to metabolic protein supply is still unclear. However when ruminal fermentation is limited by a deficiency in degradable $\mathrm{N}$ compounds, a reduced protein degradation in the rumen may have detrimental effects on carbohydrate fermentation (Hess et al., 2003). Under these conditions, tannins not only reduce protein supply but also energy availability through less volatile fatty acids (VFA) and a lower 
palatability, which in turn results in deficiencies of both protein and energy (Silanikove et al., 2001). Good-quality herbaceous legumes such as Vigna unguiculata or Arachis pintoi, although being well adapted to acidic soils, still often have a low dry matter yield during the dry season when they are most needed due to the decreased quality of the available grasses (Hess et al., 2002). Good-quality shrub legumes such as Leucaena leucocephala are limited in their tolerance against acidic soils thus also having a limited growth rate. In contrast, the tanniniferous shrub legumes Calliandra calothyrsus and Flemingia macrophylla have a high agronomic potential both on very acidic, low-fertility soils and under dry conditions, but the adverse effects of CT limit their extensive use as protein supplement (Hess et al., 2003; Anderson et al., 2006). Therefore, the use of mixtures of legumes with contrasting feeding value and agronomic potential could help to find a balance between availability and CT concentration of the legume supplements.

The hypotheses of the present study was that (i) the responses to exchanging V. unguiculata gradually with tanniniferous shrub legumes depend on the shrub species used as well as on the proportion of the shrub in the legume mixture and (ii) that the addition of polyethylene glycol (PEG) would contribute to prevent negative effects of the tanniniferous shrub legumes on in vitro ruminal fermentation. As tanniniferous species three major tropical shrub legumes, C. calothyrsus, F. macrophylla and L. leucocephala, were employed and gas and VFA production as well as dry matter (DM) degradation were determined using the gas transducer technique (Theodorou et al., 1994).

\section{Materials and methods}

\subsection{Experimental forages}

In order to compose the experimental grass-legume mixtures in the present study, samples of the plants were obtained from plantations of the germplasm collection of the Centro Internacional de Agricultura Tropical (CIAT). This included the tropical lowquality grass Brachiaria humidicola (CIAT accession No. 6133) and the legume species V. unguiculata (CIAT 391), C. calothyrsus (CIAT 22316), F. macrophylla (CIAT 17403), L. leucocephala (CIAT 734) and Cratylia argentea (CIAT 18516) all cultivated as pure stands. B. humidicola, $V$. unguiculata, F. macrophylla and $C$. argentea were grown on an Ultisol in Santander de Quilichao (Cauca, Colombia, N $3^{\circ} 06^{\prime}$, W 76 $31^{\prime}$, $990 \mathrm{~m}$ elevation, $1700 \mathrm{~mm}$ annual precipitation, $24^{\circ} \mathrm{C}$ average temperature). C. calothyrsus and L. leucocephala were grown on a Mollisol in Palmira (Valle del Cauca, Colombia, N $3^{\circ} 30^{\prime}$, W $76^{\circ} 21,968 \mathrm{~m}$ elevation, $896 \mathrm{~mm}$ annual precipitation, $24^{\circ} \mathrm{C}$ average temperature) as no plantations were available in Santander de Quilichao. As material for the experiments, only the youngest three fully developed leaves of actively growing branches were harvested manually from the shrub legumes 8 weeks after the last cut. The leaves were immediately put on ice and were stored at $-20^{\circ} \mathrm{C}$ until being freeze-dried. For $B$. humidicola (12 weeks of re-growth) and V. unguiculata ( 8 weeks after establishment) the complete above ground mass was harvested. Both herbaceous forages were sun dried for 2 days. All dried plant material was ground, in a Wiley laboratory mill fitted with a $1 \mathrm{~mm}$ sieve. 


\subsection{In vitro experiments}

In Experiment $1, B$. humidicola, $V$. unguiculata and $C$. calothyrsus were tested either alone or in various combinations. The grass-legume combinations consisted of the basal forage and either $1 / 3$ or $2 / 3$ of legume. The legumes were $V$. unguiculata and $C$. calothyrsus in ratios of $5: 0,4: 1,3: 2,2: 3,1: 4$ or $0: 5$. Overall, this resulted in 15 different combinations. In Experiment 2, B. humidicola was evaluated either alone or in combination with legumes (1/3 of DM). The legumes were V. unguiculata, C. calothyrsus, F. macrophylla, $C$. argentea and L. leucocephala. The grass-legume combinations consisted of the basal forage and a mixture of $V$. unguiculata with one of the four shrub legumes in ratios of 3:0, 2:1, $1: 2$ and $0: 3$. This added up to 14 different combinations. In both experiments, every combination was tested with and without the addition of PEG, a water-soluble synthetic polymer that forms stable complexes with tannins and thus prevents CT to complex nutrients (Bhatta et al., 2002). This was done in order to separate as complete as possible the effect of tannins from other plant-specific effects on fermentation (Silanikove et al., 2001). For that purpose, the ground plant material was treated either with distilled water or an aqueous solution $(100 \mathrm{mg} / \mathrm{ml}$ ) of PEG (average molecular weight of $8000 \mathrm{~g}$ ) resulting in a final PEG concentration of $35 \mathrm{~g} / \mathrm{kg}$ forage DM. This relation was chosen due to results of previous experiments which suggested this concentration of PEG to be sufficient to neutralize most tannin effects (Hess et al., 2004). Either distilled water or the PEG solution were incorporated into the forages by thorough mixing with a spatula until the plant material showed a homogenous moist texture. These mixtures were then air dried at $40^{\circ} \mathrm{C}$ over night.

Forage combinations were tested for in vitro ruminal fermentation characteristics with the gas pressure transducer technique as described by Theodorou et al. (1994). One gram of forage DM (with or without extra $35 \mathrm{mg}$ PEG) was weighed into serum bottles with $150 \mathrm{ml}$ capacity. Bottles were filled with $85 \mathrm{ml}$ of a mixture of mineral and buffer solution and $4 \mathrm{ml}$ of reducing agent (Menke and Steingass, 1988). After adding $10 \mathrm{ml}$ of rumen fluid, three replications of each treatment were incubated in a pre-heated water bath at $39{ }^{\circ} \mathrm{C}$. Additionally, six blanks without plant material but with buffer solution, reducing agent and rumen fluid were incubated in each experiment. The mixed rumen fluid was collected from two rumen cannulated steers grazing on a pasture dominated by star grass (Cynodon plectostachyus, medium feed quality). The rumen fluid was transported in a pre-heated vacuum container and, subsequently, solids were removed by filtering through three layers of gauze. The $\mathrm{pH}$ of the fresh rumen fluid was 6.5 and the redox potential was $-300 \mathrm{mV}$. The serum bottles were sealed by means of a rubber stopper and the gas pressure was set to zero using a transducer and a LED digital readout voltmeter. Gas pressure and volume were recorded at 3, 6, 9, 12, 24, 36, 48, 60, 72, 96, 120 and $144 \mathrm{~h}$ after the inoculation. After the last measurement, the bottles were stored at $4{ }^{\circ} \mathrm{C}$ until further processing. An amount of $30 \mathrm{ml}$ of the fermentation fluid was centrifuged on ice for $15 \mathrm{~min}$ at $30,000 \times \mathrm{g}$. Subsamples of the supernatant were taken for subsequent determination of $\mathrm{pH}$, redox potential and volatile fatty acid (VFA) concentration. For VFA determination, $1.6 \mathrm{ml}$ of fermentation fluid was deproteinised with $0.4 \mathrm{ml}$ methaphosphoric acid $(250 \mathrm{~g} / \mathrm{l})$. Subsequently, samples were stored at $-20^{\circ} \mathrm{C}$ until later processing. The remainder of the fermentation fluid was vacuum filtered together with the solid residue through a pre-weighed crucible in order to 
determine the residual DM. The bottles were rinsed with a small amount of warm, distilled water to remove all solid residues.

\subsection{Laboratory analyses}

Individual forages were subjected to analysis of DM $\left(24 \mathrm{~h}\right.$ at $\left.105^{\circ} \mathrm{C}\right)$, total ash $(3 \mathrm{~h}$ at $500^{\circ} \mathrm{C}$ ), crude protein $(\mathrm{CP}$ calculated as Kjeldahl $\mathrm{N} \times 6.25$; AOAC, 1990; ID 954.01), neutral detergent fibre (NDF), acid detergent fibre (ADF) (Van Soest et al., 1991) and acid detergent lignin (lignin (sa)). The NDF was determined without the use of $\alpha$-amylase but with the addition of sodium sulphite as recommended by Robbins et al. (1987) for tannin-containing forages to remove insoluble protein-tannin complexes. Nevertheless, a certain bias by tannins in fibre determination cannot be excluded (Makkar et al., 1995b). Lignin was determined by solubilization of cellulose with sulphuric acid (Robertson and Van Soest, 1981). Values of NDF, ADF and lignin were not corrected for ash content. Contents of extractable and bound CT in individual forages were determined as suggested by Terrill et al. (1992). Purified tannins, extracted from each material by the procedure of Hagerman and Butler (1980), were used as standards. Solid fermentation residues were analyzed for $\mathrm{DM}$ and $\mathrm{CP}$ as described above for individual forages.

Analyses of $\mathrm{pH}$ (combination $\mathrm{pH}$-electrode, model 8102 ross, Orion Research Inc., Beverly, MA, USA) and redox potential (combination platinum ring redox electrode, model DM140-SC, Mettler Toledo, Greifensee, Switzerland) in fermentation fluid were performed with a potentiometer (model 720 plus, Orion Research Inc., Beverly, MA, USA). Concentrations of VFA were determined using a high-performance liquid chromatograph (CL-10A, Shimadzu) equipped with an organic acid analysis column $(300 \mathrm{~mm} \times 7.8 \mathrm{~mm}$ i.d.; Aminex HPX-87H, Bio-Rad Laboratories, Hercules, CA, USA). An UV-vis-detector (Shimadzu SPD 10AV UV-vis Detector, Shimadzu) was used at $210 \mathrm{~nm}$ and oven temperature was $60{ }^{\circ} \mathrm{C}$. As mobile phase, $0.006 \mathrm{M} \mathrm{H}_{2} \mathrm{SO}_{4}$ was used at $0.9 \mathrm{ml} / \mathrm{min}$.

\subsection{Calculations and statistical analysis}

Gas production data were fitted to the exponential model of Gompertz (Beuvink and Kogut, 1993) where $\mu_{0} / D$ was replaced by the simplified factor $B$ as suggested by Noguera et al. (2004), using the NLIN procedure of SAS (Version 8.2 for Linux, SAS Institute, Cary, USA):

$$
y=A \mathrm{e}^{-B \mathrm{e}^{-C t}}
$$

where $y$ is the cumulative total gas production $(\mathrm{ml})$ at time $t ; A$ represents total gas production (asymptotic value) ( $\mathrm{ml} / \mathrm{g}), B$ the latency period before gas production starts (lag phase) (h) and $C$ is the specific gas production rate (slope) (total gas in $\mathrm{ml} / \mathrm{h}$ ). Among the different modified Gompertz models, this is one of the most generalized and fitted best to the processed data.

The apparent in vitro dry matter degradability (IVDMD) was calculated as the difference of DM supplied and recovered after $144 \mathrm{~h}$ of fermentation, and was corrected for the DM recovered from the blanks. This was done assuming that PEG was completely soluble and thus the solid residues were free of PEG. This simplification did not account 
for the tannin-PEG complexes which were probably present as artefacts in the undigested residue (Makkar et al., 1995a; Makkar, 2000). Therefore, the degradability of those PEGsupplemented forage combinations which contained tanniniferous legumes was probably underestimated. The apparently undegraded CP (UDCP) was calculated from the $\mathrm{N}$ content present in the solid fermentation residues, corrected for $\mathrm{N}$ recovered from the blanks. This was done assuming that all $\mathrm{N}$ determined in the residue originated only from undegraded plant protein, although residual microbial matter attached to the solid residues might have led to an overestimation of the undegraded CP.

Data were subjected to analysis of variance, using the GLM procedure of SAS (Version 8.2 for Windows, SAS Institute, Cary, NC, USA). In Experiment 1, the analyses were performed regarding the $2 \times 6 \times 2$ factorial arrangement of treatments. Legume proportion $(1 / 3$ or $2 / 3)$, replacement ratio $(5: 0,4: 1,3: 2,2: 3,1: 4$ or $0: 5)$, PEG addition (with or without PEG) and the respective interactions were considered as sources of variation. The individual forages were not considered in these analyses. Additionally, orthogonal contrasts were used to partition treatment effects in order to be able to specify linear and non-linear (quadratic) effects of the proportion of $C$. calothyrsus in the legume mixture. For this purpose, only treatments without PEG addition and with legume proportions of $1 / 3$ or $2 / 3$ were analysed, and this separately. In Experiment 2, the analyses were performed regarding the $4 \times 3 \times 2$ factorial arrangement of treatments. Legume species (C. calothyrsus, F. macrophylla, $L$. leucocephala or C. argentea), replacement ratio $(2: 1,1: 2$ or $0: 3)$ and the respective interactions were considered as sources of variation. The treatments with $V$. unguiculata as the only legume were not considered in these analyses.

\section{Results}

The forages used in the present study substantially varied in nutrient composition (Table 1). Compared to the grass, all legumes were four to six times higher in CP con-

Table 1

Chemical composition (g/kg DM) of the experimental forage species $(n=4)$

\begin{tabular}{|c|c|c|c|c|c|c|c|c|}
\hline \multirow[t]{2}{*}{ Forage species } & \multirow{2}{*}{$\begin{array}{l}\text { Organic } \\
\text { matter }\end{array}$} & \multirow{2}{*}{$\begin{array}{l}\text { Crude } \\
\text { protein }\end{array}$} & \multirow[t]{2}{*}{$\mathrm{NDF}^{\mathrm{a}}$} & \multirow[t]{2}{*}{$\mathrm{ADF}^{\mathrm{b}}$} & \multirow[t]{2}{*}{ Lignin } & \multicolumn{3}{|c|}{ Condensed tannins } \\
\hline & & & & & & Total & Extractable & Bound \\
\hline \multicolumn{9}{|l|}{ Grass } \\
\hline B. humidicola & 908 & 43 & 742 & 360 & 29 & n.d. ${ }^{\mathrm{c}}$ & n.d. & n.d. \\
\hline \multicolumn{9}{|c|}{ Tannin-free herbaceous legume (control) } \\
\hline V. unguiculata & 899 & 181 & 612 & 331 & 50 & n.d. & n.d. & n.d. \\
\hline \multicolumn{9}{|l|}{ Shrub legumes } \\
\hline C. calothyrsus & 953 & 193 & 205 & 130 & 22 & 263 & 246 & 17 \\
\hline F. macrophylla & 962 & 182 & 372 & 224 & 80 & 48 & 48 & n.d. \\
\hline L. leucocephala & 930 & 238 & 431 & 167 & 67 & 46 & 42 & 4 \\
\hline C. argentea & 916 & 258 & 423 & 232 & 79 & n.d. & n.d. & n.d. \\
\hline
\end{tabular}

${ }^{\text {a }}$ NDF, neutral detergent fibre.

b ADF, acid detergent fibre.

c not detected. 
Table 2

Calculated chemical composition ( $\mathrm{g} / \mathrm{kg} \mathrm{DM}$ ) of forage mixtures based on Brachiaria humidicola containing either $1 / 3$ or $2 / 3$ of legume (Experiment 1 )

\begin{tabular}{lllllllr}
\hline $\begin{array}{l}\text { Legume } \\
\text { proportion }\end{array}$ & $\begin{array}{l}\text { V. unguiculata: } \\
\text { C. calothyrsus }\end{array}$ & $\begin{array}{l}\text { Organic } \\
\text { matter }\end{array}$ & $\begin{array}{l}\text { Crude } \\
\text { protein }\end{array}$ & NDF $^{\mathrm{a}}$ & ADF $^{\mathrm{b}}$ & $\begin{array}{l}\text { Lignin } \\
\text { Condensed } \\
\text { tannins }\end{array}$ \\
\hline $1 / 3$ & $5: 0$ & 905 & 89 & 699 & 350 & 36 & 0 \\
$1 / 3$ & $4: 1$ & 909 & 90 & 672 & 337 & 34 & 18 \\
$1 / 3$ & $3: 2$ & 912 & 91 & 644 & 324 & 32 & 35 \\
$1 / 3$ & $2: 3$ & 916 & 91 & 617 & 310 & 30 & 53 \\
$1 / 3$ & $1: 4$ & 919 & 92 & 590 & 297 & 29 & 70 \\
$1 / 3$ & $0: 5$ & 923 & 93 & 563 & 283 & 27 & 88 \\
$2 / 3$ & $5: 0$ & 902 & 135 & 655 & 341 & 43 & 0 \\
$2 / 3$ & $4: 1$ & 909 & 137 & 601 & 314 & 39 & 35 \\
$2 / 3$ & $3: 2$ & 916 & 138 & 547 & 287 & 36 & 70 \\
$2 / 3$ & $2: 3$ & 924 & 140 & 493 & 260 & 32 & 105 \\
$2 / 3$ & $1: 4$ & 931 & 141 & 438 & 233 & 28 & 140 \\
$2 / 3$ & $0: 5$ & 938 & 143 & 384 & 207 & 24 & 175 \\
\hline
\end{tabular}

${ }^{a}$ NDF, neutral detergent fibre.

b ADF, acid detergent fibre.

tent and poorer in fibre content. Lignin contents varied widely among forage species. With the exception of $C$. calothyrsus all legume species presented considerably higher lignin contents than the grass. The tanniniferous legumes also had widely differing tannin contents. The content of total CT was more than five times higher in C. calothyrsus than in F. macrophylla and L. leucocephala. Due to the variations in the chemical composition of

Table 3

Calculated chemical composition ( $\mathrm{g} / \mathrm{kg} \mathrm{DM}$ ) of forage mixtures based on Brachiaria humidicola containing 1/3 of legume

\begin{tabular}{lllllllr}
\hline $\begin{array}{l}\text { Shrub legume } \\
\text { species }\end{array}$ & $\begin{array}{l}\text { V. unguiculata: } \\
\text { shrub legume }\end{array}$ & $\begin{array}{l}\text { Organic } \\
\text { matter }\end{array}$ & $\begin{array}{l}\text { Crude } \\
\text { protein }\end{array}$ & NDF $^{\mathrm{a}}$ & ADF $^{\mathrm{b}}$ & Lignin & $\begin{array}{l}\text { Condensed } \\
\text { tannins }\end{array}$ \\
\hline- & $3: 0$ & 905 & 89 & 699 & 350 & 36 & 0 \\
C. calothyrsus & $2: 1$ & 911 & 90 & 653 & 328 & 33 & 29 \\
C. calothyrsus & $1: 2$ & 917 & 92 & 608 & 306 & 30 & 58 \\
C. calothyrsus & $0: 3$ & 923 & 93 & 563 & 283 & 27 & 88 \\
F. macrophylla & $2: 1$ & 912 & 89 & 672 & 338 & 39 & 5 \\
F. macrophylla & $1: 2$ & 919 & 89 & 645 & 327 & 43 & 11 \\
F. macrophylla & $0: 3$ & 926 & 89 & 619 & 315 & 46 & 16 \\
L. leucocephala & $2: 1$ & 908 & 95 & 679 & 332 & 38 & 5 \\
L. leucocephala & $1: 2$ & 912 & 102 & 658 & 314 & 40 & 10 \\
L. leucocephala & $0: 3$ & 915 & 108 & 638 & 296 & 42 & 15 \\
C. argentea & $2: 1$ & 907 & 98 & 678 & 339 & 39 & 0 \\
C. argentea & $1: 2$ & 909 & 106 & 657 & 328 & 42 & 0 \\
C. argentea & $0: 3$ & 911 & 115 & 636 & 317 & 46 & 0 \\
\hline
\end{tabular}

The legume part of the mixtures consisted of Vigna unguiculata alone or in combination with a shrub legume (Experiment 2).

${ }^{\text {a }}$ NDF, neutral detergent fibre.

b ADF, acid detergent fibre. 
the individual forage species, the forage mixtures tested in Experiment 1 (Table 2) and 2 (Table 3) differed also in their CP, fibre and CT contents.

\subsection{Experiment 1}

The IVDMD was clearly affected by the legume proportion in the total mixture $(\mathrm{P}<0.001)$ and the ratio of V. unguiculata:C. calothyrsus $(\mathrm{P}<0.001)$ in the legume mixture (Table 4$)$. The

Table 4

Apparent in vitro dry matter degradability (IVDMD), initial latency and rate of gas production of B. humidicola, $V$. unguiculata and $C$. calothyrsus alone or in various combinations incubated with or without polyethylene glycol (PEG) (Experiment $1 ; n=3$ )

\begin{tabular}{|c|c|c|c|c|c|c|c|c|}
\hline \multirow[t]{2}{*}{$\begin{array}{l}\text { B. humidicola } \\
\text { proportion }\end{array}$} & \multirow[t]{2}{*}{$\begin{array}{l}\text { Legume } \\
\text { proportion }\end{array}$} & \multirow[t]{2}{*}{$\begin{array}{l}\text { V. unguiculata: } \\
\text { C. calothyrsus }\end{array}$} & \multicolumn{2}{|c|}{ IVDMD (g/kg) } & \multicolumn{2}{|c|}{$\begin{array}{l}\text { Initial latency } \\
\text { (h) (B) }\end{array}$} & \multicolumn{2}{|c|}{$\begin{array}{l}\text { Gas production } \\
\text { rate }(\mathrm{ml} / \mathrm{h})(\mathrm{C})\end{array}$} \\
\hline & & & $-\mathrm{PEG}$ & + PEG & $-\mathrm{PEG}$ & $+\mathrm{PEG}$ & $-\mathrm{PEG}$ & + PEG \\
\hline 1 & 0 & & 730 & 808 & 2.97 & 2.86 & 0.0464 & 0.0458 \\
\hline 0 & 1 & $1: 0$ & 694 & 756 & 2.89 & 2.80 & 0.0678 & 0.0652 \\
\hline 0 & 1 & $0: 1$ & 480 & 543 & 2.70 & 2.70 & 0.0310 & 0.0404 \\
\hline $2 / 3$ & $1 / 3$ & $5: 0$ & 729 & 793 & 2.86 & 2.73 & 0.0529 & 0.0519 \\
\hline $2 / 3$ & $1 / 3$ & $4: 1$ & 722 & 778 & 3.06 & 2.71 & 0.0521 & 0.0521 \\
\hline $2 / 3$ & $1 / 3$ & $3: 2$ & 702 & 767 & 3.06 & 2.68 & 0.0486 & 0.0513 \\
\hline $2 / 3$ & $1 / 3$ & $2: 3$ & 679 & 749 & 3.17 & 2.67 & 0.0469 & 0.0501 \\
\hline $2 / 3$ & $1 / 3$ & $1: 4$ & 669 & 737 & 3.42 & 2.71 & 0.0452 & 0.0490 \\
\hline $2 / 3$ & $1 / 3$ & $0: 5$ & 645 & 737 & 3.37 & 2.72 & 0.0425 & 0.0455 \\
\hline $1 / 3$ & $2 / 3$ & $5: 0$ & 728 & 768 & 2.82 & 2.74 & 0.0586 & 0.0597 \\
\hline $1 / 3$ & $2 / 3$ & $4: 1$ & 692 & 756 & 2.90 & 2.78 & 0.0553 & 0.0542 \\
\hline $1 / 3$ & $2 / 3$ & $3: 2$ & 676 & 732 & 3.07 & 2.66 & 0.0511 & 0.0513 \\
\hline $1 / 3$ & $2 / 3$ & $2: 3$ & 634 & 701 & 3.17 & 2.69 & 0.0462 & 0.0504 \\
\hline $1 / 3$ & $2 / 3$ & $1: 4$ & 591 & 675 & 3.06 & 2.56 & 0.0402 & 0.0477 \\
\hline $1 / 3$ & $2 / 3$ & $0: 5$ & 558 & 629 & 3.05 & 2.70 & 0.0318 & 0.0460 \\
\hline \multicolumn{3}{|l|}{ SEM } & \multicolumn{2}{|c|}{6.0} & \multicolumn{2}{|c|}{0.050} & \multicolumn{2}{|c|}{0.00043} \\
\hline \multicolumn{9}{|c|}{ Significance $^{\mathrm{a}}$} \\
\hline \multicolumn{3}{|c|}{ Legume proportion (LP) } & \multicolumn{2}{|l|}{$* * *$} & \multicolumn{2}{|l|}{$* * *$} & \multicolumn{2}{|l|}{ * } \\
\hline \multicolumn{3}{|c|}{ V. unguiculata:C. calothyrus ratio (R) } & \multicolumn{2}{|l|}{$* * *$} & \multicolumn{2}{|l|}{$* * *$} & \multicolumn{2}{|l|}{ *** } \\
\hline \multicolumn{3}{|c|}{ Polyethylene glycol (PEG) } & \multicolumn{2}{|l|}{$* * *$} & \multicolumn{2}{|l|}{$* * *$} & \multicolumn{2}{|l|}{$* * *$} \\
\hline \multicolumn{3}{|c|}{$\mathrm{LP} \times \mathrm{R}$} & \multicolumn{2}{|l|}{$* * *$} & \multicolumn{2}{|l|}{ ** } & \multicolumn{2}{|l|}{$* * *$} \\
\hline \multicolumn{3}{|l|}{$\mathrm{LP} \times \mathrm{PEG}$} & & $* *$ & & **** & \\
\hline $\mathrm{R} \times \mathrm{PEG}$ & & & $* *$ & & $* * *$ & & $* * *$ & \\
\hline $\mathrm{LP} \times \mathrm{R} \times \mathrm{PE}$ & & & & & & & $* * *$ & \\
\hline Contrasts $(-$ & EG) & & & & & & & \\
\hline 1/3 legum & & & & & & & & \\
\hline $\begin{array}{l}\text { Linear } \\
\text { Quadrat }\end{array}$ & & & $* * *$ & & $* * *$ & & $* * *$ & \\
\hline 2/3 legum & & & & & & & & \\
\hline Linear & & & $* * *$ & & $* * *$ & & **** & \\
\hline Quadrat & & & $*$ & & $*$ & & $* * *$ & \\
\hline
\end{tabular}

\footnotetext{
${ }^{a}$ Individual forages were not considered in the statistical analyses.

* $\mathrm{P}<0.05$.

** $\mathrm{P}<0.01$.

*** $\mathrm{P}<0.001$.
} 


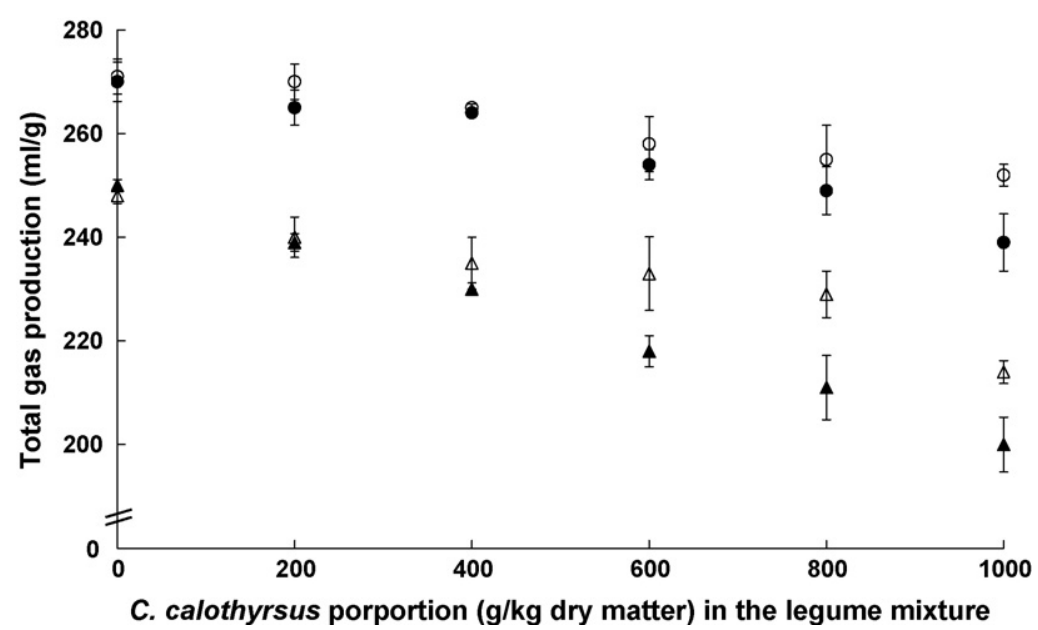

Fig. 1. Total gas production after $144 \mathrm{~h}$ of incubation of forage mixtures based on Brachiaria humidicola containing either $1 / 3(\boldsymbol{O}, \bigcirc)$ or $2 / 3(\boldsymbol{\Delta}, \Delta)$ of legume foliage. The legume part of the mixtures consisted either of Vigna unguiculata or Calliandra calothyrsus alone or different combinations of the two legumes. All mixtures were tested with $(\triangle, \bigcirc)$ and without $(\boldsymbol{\Lambda}, \mathbf{O})$ the addition of polyethylene glycol (PEG) (Experiment $1 ; n=3$ ).

highest IVDMD values were observed with pure $B$. humidicola and with the grass-legume combinations which contained $V$. unguiculata as the only legume. In both the low-legume (1/3 of DM) and the high-legume treatments (2/3 of DM), IVDMD decreased linearly $(\mathrm{P}<0.001)$ with increasing proportion of $C$. calothyrsus, but the decrease was much larger in the high-legume than in the low-legume treatments (interaction, $\mathrm{P}<0.001$ ). Supplementing PEG widely but not completely prevented the effect of $C$. calothyrsus on IVDMD which also resulted in an interaction $(\mathrm{P}<0.01)$ between the $C$. calothyrsus proportion in the legume mixture and PEG addition. The effects on total gas production (A) of legume proportion, ratio of V. unguiculata:C. calothyrsus and addition of PEG were very similar to those on IVDMD. On average, the total gas production was higher $(\mathrm{P}<0.001)$ with the low-legume than with the high-legume treatments (Fig. 1). Independent of the legume proportion in the mixture, the total gas production decreased $(\mathrm{P}<0.001)$ with increasing $C$. calothyrsus proportion in the legume part, and this effect was more pronounced in the high-legume than in the low-legume treatments (interaction, $\mathrm{P}<0.001$ ). Initial latency period $(\mathrm{B})$ increased $(\mathrm{P}<0.001)$ with increasing $C$. calothyrsus proportion in the legume mixture, and was higher $(\mathrm{P}<0.001)$ in the low-legume treatments than in the high-legume treatments (Table 4). These effects were not apparent when PEG was added to the mixtures (interaction, $\mathrm{P}<0.01$ ). Gas production rate was highest with mixtures which were free of $C$. calothyrsus and decreased $(\mathrm{P}<0.001)$ with increasing proportion of $C$. calothyrsus in the mixture.

Differences among treatments in fermentation fluid $\mathrm{pH}$ and redox potential (data not shown) were small and mostly not significant. Across all treatments, mean $\mathrm{pH}$ was 7.24 and average redox potential was $-352 \mathrm{mV}$. The total concentration of VFA was affected by the legume proportion $(\mathrm{P}<0.001)$ and the ratio of $V$. unguiculata: $C$. calothyrsus $(\mathrm{P}<0.001)$ (Table 5). The highest VFA concentrations were observed with pure $B$. humidicola and with the grass-legume combinations which did not contain any $C$. calothyrsus. Total VFA 
Table 5

Volatile fatty acid concentration and acetate-to-propionate ratio in the fermentation fluid and proportion of apparently undegraded crude protein (UDCP) of B. humidicola, V. unguiculata and C. calothyrsus alone or in various combinations incubated with or without polyethylene glycol (PEG) (Experiment $1 ; n=3$ )

\begin{tabular}{|c|c|c|c|c|c|c|c|c|}
\hline \multirow[t]{2}{*}{$\begin{array}{l}\text { B. humidicola } \\
\text { proportion }\end{array}$} & \multirow[t]{2}{*}{$\begin{array}{l}\text { Legume } \\
\text { proportion }\end{array}$} & \multirow[t]{2}{*}{$\begin{array}{l}\text { V. unguiculata: } \\
\text { C. calothyrsus }\end{array}$} & \multicolumn{2}{|c|}{$\begin{array}{l}\text { Volatile fatty } \\
\text { acids (mmol/l) }\end{array}$} & \multicolumn{2}{|c|}{$\begin{array}{l}\text { Acetate/ } \\
\text { propionate }\end{array}$} & \multicolumn{2}{|c|}{$\begin{array}{l}\text { UDCP }(\mathrm{g} / \mathrm{kg} \\
\text { of N supplied) }\end{array}$} \\
\hline & & & $-\mathrm{PEG}$ & $+\mathrm{PEG}$ & $-\mathrm{PEG}$ & $+\mathrm{PEG}$ & $-\mathrm{PEG}$ & $+\mathrm{PEG}$ \\
\hline 1 & 0 & & 70.2 & 62.3 & 2.48 & 2.89 & 491 & 210 \\
\hline 0 & 1 & $1: 0$ & 62.9 & 58.2 & 1.47 & 1.68 & 208 & 215 \\
\hline 0 & 1 & $0: 1$ & 36.0 & 52.5 & 5.56 & 2.11 & 857 & 555 \\
\hline $2 / 3$ & $1 / 3$ & $5: 0$ & 66.3 & 66.6 & 2.28 & 2.05 & 321 & 245 \\
\hline $2 / 3$ & $1 / 3$ & $4: 1$ & 57.5 & 61.4 & 2.93 & 2.60 & 340 & 204 \\
\hline $2 / 3$ & $1 / 3$ & $3: 2$ & 57.9 & 61.5 & 2.85 & 2.34 & 411 & 223 \\
\hline $2 / 3$ & $1 / 3$ & $2: 3$ & 57.3 & 60.9 & 3.22 & 2.51 & 515 & 225 \\
\hline $2 / 3$ & $1 / 3$ & $1: 4$ & 56.2 & 61.6 & 3.00 & 2.49 & 606 & 283 \\
\hline $2 / 3$ & $1 / 3$ & $0: 5$ & 56.8 & 60.8 & 2.79 & 2.50 & 678 & 281 \\
\hline $1 / 3$ & $2 / 3$ & $5: 0$ & 55.8 & 56.7 & 2.58 & 2.48 & 244 & 219 \\
\hline $1 / 3$ & $2 / 3$ & $4: 1$ & 59.5 & 66.0 & 2.24 & 1.67 & 340 & 185 \\
\hline $1 / 3$ & $2 / 3$ & $3: 2$ & 54.1 & 60.2 & 2.57 & 1.95 & 432 & 217 \\
\hline $1 / 3$ & $2 / 3$ & $2: 3$ & 50.2 & 58.2 & 3.05 & 2.01 & 540 & 271 \\
\hline $1 / 3$ & $2 / 3$ & $1: 4$ & 48.6 & 64.3 & 3.21 & 1.85 & 700 & 333 \\
\hline $1 / 3$ & $2 / 3$ & $0: 5$ & 44.4 & 56.2 & 3.99 & 2.62 & 825 & 476 \\
\hline \multicolumn{3}{|l|}{ SEM } & \multicolumn{2}{|c|}{1.96} & \multicolumn{2}{|c|}{0.210} & \multicolumn{2}{|c|}{22.4} \\
\hline \multicolumn{9}{|l|}{ Significance $^{\mathrm{a}}$} \\
\hline \multicolumn{3}{|c|}{ Legume proportion (LP) } & \multicolumn{2}{|l|}{$* * *$} & & \multicolumn{2}{|l|}{$* * *$} \\
\hline \multicolumn{3}{|c|}{ V. unguiculata:C. calothyrus ratio $(\mathrm{R})$} & \multicolumn{2}{|l|}{$* * *$} & \multicolumn{2}{|l|}{$* * *$} & \multicolumn{2}{|l|}{ **** } \\
\hline \multicolumn{3}{|c|}{ Polyethylene glycol (PEG) } & \multicolumn{2}{|l|}{$* * *$} & \multicolumn{2}{|l|}{$* * *$} & \multicolumn{2}{|l|}{$* * *$} \\
\hline \multicolumn{3}{|c|}{$\mathrm{LP} \times \mathrm{R}$} & \multicolumn{2}{|l|}{$* * *$} & \multicolumn{2}{|l|}{ *** } & \multicolumn{2}{|l|}{ **** } \\
\hline \multicolumn{3}{|l|}{$\mathrm{LP} \times \mathrm{PEG}$} & \multicolumn{2}{|l|}{$* *$} & ** & & & \\
\hline $\begin{array}{l}\mathrm{R} \times \mathrm{PEG} \\
\mathrm{LP} \times \mathrm{R} \times \mathrm{PE}\end{array}$ & & & * & & * & & $* * *$ & \\
\hline Contrasts $(-$ & EG) & & & & & & & \\
\hline 1/3 legum & & & & & & & & \\
\hline Linear & & & $* *$ & & * & & $* * *$ & \\
\hline Quadra & & & $*$ & & $* *$ & & $*$ & \\
\hline 2/3 legum & & & & & & & & \\
\hline Linear & & & $* * *$ & & $* * *$ & & $* * *$ & \\
\hline Quadra & & & * & & $* *$ & & * & \\
\hline
\end{tabular}

\footnotetext{
${ }^{\mathrm{a}}$ Individual forages were not considered in the statistical analyses.

${ }^{*} \mathrm{P}<0.05$.

** $\mathrm{P}<0.01$.

*** $\mathrm{P}<0.001$.
}

concentration decreased linearly $(\mathrm{P}<0.01)$ with increasing $C$. calothyrsus proportion in the mixture, but differences between individual treatments were small. The PEG addition prevented these effects on total VFA concentration which resulted in an interaction $(\mathrm{P}<0.001)$ between $C$. calothyrsus proportion and PEG addition. Differences among treatments in the acetate-to-propionate ratio were relatively small, except with $C$. calothyrsus alone ver- 
sus the other treatments. The ratio increased linearly $(\mathrm{P}<0.05)$ with rising proportion of C. calothyrsus, and this effect was more pronounced in the high-legume treatments than in the low-legume treatments (interaction, $\mathrm{P}<0.001$ ). The addition of PEG widely eliminated such developments associated with increasing C. calothyrsus proportions (interaction, $\mathrm{P}<0.001)$.

There were huge differences across treatments in the proportion of UDCP. Increasing proportions of $C$. calothyrsus in the legume mixture linearly increased $(\mathrm{P}<0.001)$ the proportion of UDCP. The addition of PEG prevented most, but not all, of the $C$. calothyrsus effects on UDCP (interaction, $\mathrm{P}<0.001$ ). Accordingly, the maximum increase with $C$. calothyrsus in the proportion of apparently undegraded crude protein was from 244 to $825 \mathrm{~g} / \mathrm{kg}$ of CP supplied without and from 219 to $476 \mathrm{~g} / \mathrm{kg}$ with PEG.

Table 6

Apparent in vitro dry matter degradability (IVDMD), initial latency and rate of gas production of forage mixtures based on Brachiaria humidicola

\begin{tabular}{|c|c|c|c|c|c|c|c|c|}
\hline \multirow[t]{2}{*}{$\begin{array}{l}\text { B. humidicola } \\
\text { proportion }\end{array}$} & \multirow[t]{2}{*}{$\begin{array}{l}\text { Shrub legume } \\
\text { species }\end{array}$} & \multirow[t]{2}{*}{$\begin{array}{l}\text { V. unguiculata: } \\
\text { shrub legume }\end{array}$} & \multicolumn{2}{|c|}{$\begin{array}{l}\text { IVDMD } \\
(\mathrm{g} / \mathrm{kg})\end{array}$} & \multicolumn{2}{|c|}{$\begin{array}{l}\text { Initial latency } \\
\text { (h) (B) }\end{array}$} & \multicolumn{2}{|c|}{$\begin{array}{l}\text { Gas production } \\
\text { rate }(\mathrm{ml} / \mathrm{h})(\mathrm{C})\end{array}$} \\
\hline & & & $-\mathrm{PEG}$ & $+\mathrm{PEG}$ & $-\mathrm{PEG}$ & $+\mathrm{PEG}$ & $-\mathrm{PEG}$ & $+\mathrm{PEG}$ \\
\hline 1 & & & 665 & 664 & 3.02 & 2.98 & 0.0485 & 0.0455 \\
\hline $2 / 3$ & & $1: 0$ & 646 & 665 & 2.84 & 2.77 & 0.0547 & 0.0538 \\
\hline $2 / 3$ & C. calothyrsus & $2: 1$ & 628 & 628 & 3.04 & 2.70 & 0.0515 & 0.0532 \\
\hline $2 / 3$ & C. calothyrsus & $1: 2$ & 590 & 598 & 3.16 & 2.73 & 0.0469 & 0.0504 \\
\hline $2 / 3$ & C. calothyrsus & $0: 3$ & 564 & 595 & 3.40 & 2.90 & 0.0414 & 0.0484 \\
\hline $2 / 3$ & F. macrophylla & $2: 1$ & 610 & 622 & 2.94 & 2.76 & 0.0527 & 0.0530 \\
\hline $2 / 3$ & F. macrophylla & $1: 2$ & 574 & 599 & 3.08 & 2.80 & 0.0503 & 0.0527 \\
\hline $2 / 3$ & F. macrophylla & $0: 3$ & 531 & 572 & 3.35 & 2.76 & 0.0468 & 0.0509 \\
\hline $2 / 3$ & L. leucocephala & $2: 1$ & 633 & 646 & 2.86 & 2.78 & 0.0541 & 0.0517 \\
\hline $2 / 3$ & L. leucocephala & $1: 2$ & 613 & 638 & 2.94 & 2.85 & 0.0514 & 0.0523 \\
\hline $2 / 3$ & L. leucocephala & $0: 3$ & 587 & 628 & 3.08 & 2.67 & 0.0501 & 0.0510 \\
\hline $2 / 3$ & C. argentea & $2: 1$ & 643 & 652 & 2.76 & 2.74 & 0.0546 & 0.0536 \\
\hline $2 / 3$ & C. argentea & $1: 2$ & 638 & 657 & 2.72 & 2.60 & 0.0548 & 0.0532 \\
\hline $2 / 3$ & C. argentea & $0: 3$ & 634 & 647 & 2.64 & 2.67 & 0.0543 & 0.0527 \\
\hline \multicolumn{3}{|l|}{ SEM } & \multicolumn{2}{|c|}{4.5} & \multicolumn{2}{|c|}{0.029} & \multicolumn{2}{|c|}{0.00043} \\
\hline \multicolumn{9}{|c|}{ Significance $^{\mathrm{a}}$} \\
\hline \multicolumn{2}{|c|}{ Shrub legume species (S) } & & \multicolumn{2}{|l|}{$* * *$} & \multicolumn{2}{|l|}{$* * *$} & \multicolumn{2}{|l|}{$* * *$} \\
\hline \multicolumn{2}{|c|}{ V. unguiculata:shrub ratio (R) } & & \multicolumn{2}{|l|}{$* * *$} & \multicolumn{2}{|l|}{$* * *$} & \multicolumn{2}{|l|}{$* * *$} \\
\hline \multicolumn{2}{|c|}{ Polyethylene glycol (PEG) } & & \multicolumn{2}{|l|}{$* * *$} & \multicolumn{2}{|l|}{$* * *$} & \multicolumn{2}{|l|}{$* * *$} \\
\hline \multicolumn{2}{|c|}{$\mathrm{S} \times \mathrm{R}$} & & \multicolumn{2}{|l|}{$* * *$} & \multicolumn{2}{|l|}{$* * *$} & \multicolumn{2}{|l|}{$* * *$} \\
\hline \multicolumn{2}{|l|}{$\mathrm{S} \times \mathrm{PEG}$} & & \multicolumn{2}{|l|}{$* *$} & \multicolumn{2}{|l|}{$* * *$} & \multicolumn{2}{|l|}{$* * *$} \\
\hline \multicolumn{2}{|l|}{$\mathrm{R} \times \mathrm{PEG}$} & & $* * *$ & & $* * *$ & & $* * *$ & \\
\hline $\mathrm{S} \times \mathrm{R} \times \mathrm{PEC}$ & & & & & $* * *$ & & $* * *$ & \\
\hline
\end{tabular}

The legume part of the mixtures consisted of Vigna unguiculata alone or in combination with a shrub legume. All forages were incubated with or without polyethylene glycol (PEG) (Experiment $2 ; n=3$ ).

${ }^{a}$ Forage mixtures based on B. humidicola and V. unguiculata alone were not considered in the statistical analyses.

** $\mathrm{P}<0.01$.

*** $\mathrm{P}<0.001$. 


\subsection{Experiment 2}

As in Experiment 1, the highest IVDMD was observed in the pure $B$. humidicola treatment and the mixtures of $B$. humidicola with $V$. unguiculata (Table 6). The IVDMD was clearly affected by shrub legume species $(\mathrm{P}<0.001)$ and the ratio of $V$. unguiculata:shrub $(\mathrm{P}<0.001)$ in the legume mixture. Partial or complete replacement of $V$. unguiculata by $C$. argentea did not affect IVDMD. With any other species, the IVDMD decreased when increasing the proportion of shrub legume foliage in the mixture. However, the extent of this suppression differed among species (interaction species $\times$ ratio, $\mathrm{P}<0.001$ ) and was more pronounced with $F$. macrophylla than with $C$. calothyrsus or L. leucaena. With L. leucocephala, only the complete exchange of $V$. unguiculata substantially reduced IVDMD. The addition of PEG prevented or slowed down the decline in IVDMD with the three tanniniferous legumes which resulted in a significant $(\mathrm{P}<0.01)$ interaction between legume species and PEG addition. The total gas production (A) responded similar as IVDMD to variations in the inclusion of legume foliage (Fig. 2). Total gas production was reduced when $V$. unguiculata was replaced by C. calothyrsus, F. macrophylla or L. leucocephala, but was not affected when $C$. argentea was included in the mixture. The latency period (B) gradually increased with the inclusion of the tanniniferous legumes $(\mathrm{P}<0.001)$, a trend which was completely prevented with PEG addition (interaction ratio $\times \mathrm{PEG}, \mathrm{P}<0.001$ ). The specific gas production rate $(\mathrm{C})$ declined $(\mathrm{P}<0.001)$ with increasing proportions of $C$. calothyrsus,
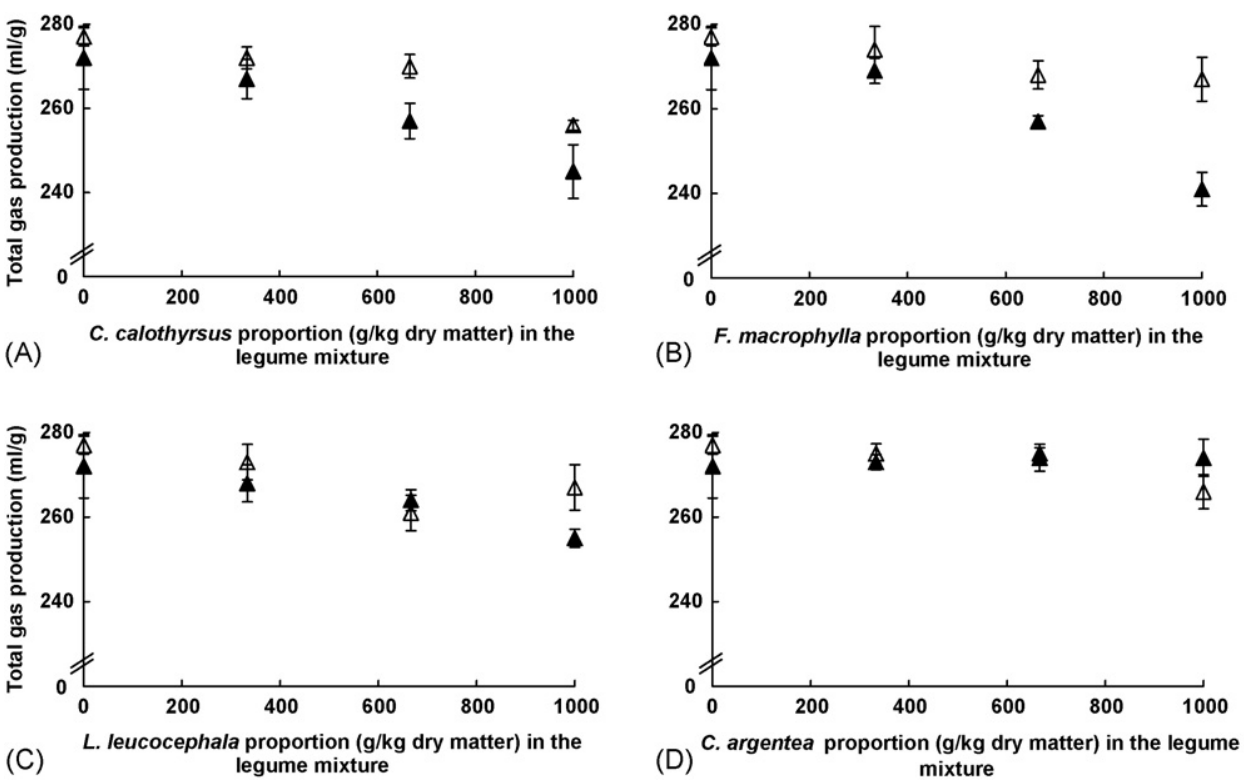

Fig. 2. Total gas production after $144 \mathrm{~h}$ of incubation of forage mixtures based on Brachiaria humidicola containing $1 / 3$ of legume foliage. The legume part of the mixtures consisted of Vigna unguiculata alone or in combination with one of the shrub legumes Calliandra calothyrsus (A), Flemingia macrophylla (B), Leucaena leucocephala (C) and Cratylia argentea (D). All mixtures were tested with $(\triangle)$ and without $(\Delta)$ the addition of polyethylene glycol (PEG) (Experiment 2; $n=3)$. 
Table 7

Volatile fatty acid concentration and acetate-to-propionate ratio in the fermentation fluid and proportion of apparently undegraded crude protein (UDCP) of forage mixtures based on Brachiaria humidicola

\begin{tabular}{|c|c|c|c|c|c|c|c|c|}
\hline \multirow[t]{2}{*}{$\begin{array}{l}\text { B. humidicola } \\
\text { proportion }\end{array}$} & \multirow[t]{2}{*}{$\begin{array}{l}\text { Shrub legume } \\
\text { species }\end{array}$} & \multirow[t]{2}{*}{$\begin{array}{l}\text { V. unguiculata: } \\
\text { shrub legume }\end{array}$} & \multicolumn{2}{|c|}{$\begin{array}{l}\text { Volatile fatty } \\
\text { acids (mmol/l) }\end{array}$} & \multicolumn{2}{|c|}{$\begin{array}{l}\text { Acetate/ } \\
\text { propionate }\end{array}$} & \multicolumn{2}{|c|}{$\begin{array}{l}\mathrm{UDCP}(\mathrm{g} / \mathrm{kg} \\
\text { of } \mathrm{N} \text { supplied) }\end{array}$} \\
\hline & & & $-\mathrm{PEG}$ & + PEG & $-\mathrm{PEG}$ & + PEG & $-\mathrm{PEG}$ & $+\mathrm{PEG}$ \\
\hline \multicolumn{3}{|l|}{1} & 68.1 & 67.1 & 2.33 & 1.99 & 414 & 413 \\
\hline \multicolumn{2}{|l|}{$2 / 3$} & $1: 0$ & 58.6 & 68.3 & 2.55 & 1.91 & 305 & 242 \\
\hline $2 / 3$ & C. calothyrsus & $2: 1$ & 62.4 & 67.6 & 2.02 & 1.72 & 399 & 286 \\
\hline $2 / 3$ & C. calothyrsus & $1: 2$ & 48.7 & 69.0 & 2.70 & 1.97 & 537 & 314 \\
\hline $2 / 3$ & C. calothyrsus & $0: 3$ & 49.3 & 64.1 & 3.14 & 2.17 & 676 & 294 \\
\hline $2 / 3$ & F. macrophylla & $2: 1$ & 61.1 & 62.4 & 2.27 & 1.78 & 428 & 303 \\
\hline $2 / 3$ & F. macrophylla & $1: 2$ & 61.4 & 70.7 & 2.31 & 1.79 & 524 & 316 \\
\hline $2 / 3$ & F. macrophylla & $0: 3$ & 51.0 & 69.6 & 2.17 & 1.81 & 710 & 339 \\
\hline $2 / 3$ & L. leucocephala & $2: 1$ & 65.7 & 69.7 & 2.10 & 1.65 & 341 & 260 \\
\hline $2 / 3$ & L. leucocephala & $1: 2$ & 62.9 & 66.3 & 2.17 & 2.13 & 400 & 258 \\
\hline $2 / 3$ & L. leucocephala & $0: 3$ & 56.6 & 63.9 & 2.40 & 2.26 & 523 & 264 \\
\hline $2 / 3$ & C. argentea & $2: 1$ & 59.1 & 67.4 & 2.25 & 1.87 & 272 & 256 \\
\hline $2 / 3$ & C. argentea & $1: 2$ & 62.0 & 67.1 & 2.44 & 1.77 & 269 & 243 \\
\hline $2 / 3$ & C. argentea & $0: 3$ & 66.3 & 66.6 & 2.01 & 1.64 & 236 & 237 \\
\hline \multicolumn{3}{|l|}{ SEM } & \multicolumn{2}{|c|}{2.67} & \multicolumn{2}{|c|}{0.161} & \multicolumn{2}{|c|}{16.4} \\
\hline \multicolumn{9}{|l|}{ Significance $^{a}$} \\
\hline \multicolumn{2}{|c|}{ Shrub legume species (S) } & & \multicolumn{2}{|l|}{$*$} & \multicolumn{2}{|l|}{ * } & \multicolumn{2}{|l|}{$* * *$} \\
\hline \multicolumn{2}{|c|}{ V. unguiculata:shrub ratio (R) } & & \multicolumn{2}{|l|}{$*$} & \multicolumn{2}{|l|}{$*$} & \multicolumn{2}{|l|}{$* * *$} \\
\hline \multicolumn{2}{|c|}{ Polyethylene glycol (PEG) } & & \multicolumn{2}{|l|}{$* * *$} & \multicolumn{2}{|l|}{$* * *$} & \multicolumn{2}{|l|}{$* * *$} \\
\hline \multicolumn{2}{|c|}{$\mathrm{S} \times \mathrm{R}$} & & \multicolumn{2}{|l|}{$*$} & \multicolumn{2}{|l|}{$* *$} & \multicolumn{2}{|l|}{$* * *$} \\
\hline \multicolumn{2}{|l|}{$\mathrm{S} \times \mathrm{PEG}$} & & \multicolumn{2}{|l|}{$*$} & & & \multicolumn{2}{|l|}{$* * *$} \\
\hline $\mathrm{R} \times \mathrm{PEG}$ & & & & & & & $* * *$ & \\
\hline $\mathrm{S} \times \mathrm{R} \times \mathrm{PEC}$ & & & $*$ & & & & $* * *$ & \\
\hline
\end{tabular}

The legume part of the mixtures consisted of Vigna unguiculata alone or in combination with a shrub legume. All forages were incubated with or without polyethylene glycol (PEG) (Experiment 2; $n=3$ ).

${ }^{a}$ Forage mixtures based on B. humidicola and $V$. unguiculata alone were not considered in the statistical analyses.

*** $\mathrm{P}<0.001$

** $\mathrm{P}<0.01$.

${ }^{*} \mathrm{P}<0.05$.

F. macrophylla or L. leucocephala, but not with C. argentea. The addition of PEG could only partially prevent this negative effect on gas production rate (Table 6).

Differences in $\mathrm{pH}$ and redox potential of the fermentation fluid due to legume species, ratio or PEG addition were occasionally significant but small in extent (data not shown in table). Across all treatments, $\mathrm{pH}$ and redox potential averaged 7.41 and $-356 \mathrm{mV}$, respectively. Concentration of total VFA was lowest with combinations containing C. calothyrsus or F. macrophylla as the only legume, and with the mixture of V. unguiculata and C. calothyrsus in a proportion of 1:2 (Table 7). With PEG addition, no significant differences in VFA concentration remained (interaction, $\mathrm{P}<0.05$ ). Changes found in acetate-to-propionate ratio were mostly inversely related to total VFA concentration, but species $\times$ PEG interaction was not significant $(\mathrm{P}>0.05)$. 
The proportion of UDCP was clearly affected by the shrub legume species and the ratio of $V$. unguiculata:shrub $(\mathrm{P}<0.001)$ in the legume mixture (Table 7). The lowest proportion of UDCP was observed in mixtures containing $C$. argentea and the highest in mixtures with $C$. calothyrsus or F. macrophylla. Mixtures with L. leucocephala showed intermediate values. The proportion of UDCP increased with increasing levels of tanniniferous shrub legumes in the mixtures but was slightly reduced when $V$. unguiculata was replaced by $C$. argentea (interaction species $\times$ ratio, $\mathrm{P}<0.001$ ). The increases found with increasing proportion of tanniniferous legumes in UDCP were either roughly linear (C. calothyrsus) or exponential (different particularly for the highest level; F. macrophylla, L. leucocephala). The addition of PEG prevented all increases in proportion of UDCP caused by the tanniniferous legumes (interaction, $\mathrm{P}<0.001$ ).

\section{Discussion}

The main objective of this work was to determine whether the responses in in vitro ruminal fermentation to exchanging $V$. unguiculata gradually with shrub legumes depend on the shrub species used and on the proportion of the shrub in the legume mixture. All legume species had relatively similar CP contents but varied widely in their fibre contents. The tanniniferous shrub legumes presented lower NDF and ADF contents than $V$. unguiculata. However, these values have to be interpreted with caution since a certain bias by tannins in fibre determination cannot be excluded (Makkar et al., 1995b).

\subsection{Suitability of the control treatments}

Controls used in both experiments were $B$. humidicola alone, single legume-grass mixtures and, in Experiment 1 only, pure legumes. The $B$. humidicola investigated was very rich in fibre and low in protein, but nevertheless showed, particularly in Experiment 1, unexpectedly high IVDMD, total gas production and total VFA production and a low acetate-to-propionate ratio when incubated alone. This suggests a reasonably high content of fermentable organic matter of B. humidicola which could be explained by the rather low lignin content. Moore and Miller (1988) analysed various species and accession of the genus Brachiaria for their cell wall composition and fibre degradability, including five accessions of $B$. humidicola of different origins. After $72 \mathrm{~h}$ of incubation, leaves and stems showed an IVDMD of 817 and $654 \mathrm{~g} / \mathrm{kg}$, respectively, which supports the favourable data found in the present $B$. humidicola batch. However, the extremely low CP content $(43 \mathrm{~g} / \mathrm{kg}$ DM) makes the grass still a poor nutrient source when fed alone.

Vigna unguiculata, incubated in mixtures with $B$. humidicola at levels of $1 / 3$ or $2 / 3$, resulted in a largely increased $\mathrm{CP}$ content in the mixture and hence an improved supply with crude protein. Contrary to previous studies (Hess et al., 2003) where the addition of a herbaceous low-tannin legume (Arachis pintoi) increased CP supply and fermentative activity, in the present experiments there was no improvement in IVDMD and VFA production (obvious from the VFA concentrations found with constant amounts of feed). However, differences in gas production dynamics suggest that degradation of $V$. unguiculata was more rapid than that of the grass-alone, most likely due to the faster accessibility of the legume fibre. 
All forage combinations, including the ones without tanniniferous legumes, were tested with and without PEG. To reduce the much discussed (Makkar et al., 1995a; Makkar, 2000) problem of underestimation of the IVDMD due to artefact formation it was decided to apply a relatively low PEG concentration. In most variables measured, PEG addition largely prevented the effects resulting from the inclusion of the three tanniniferous shrub legumes. This illustrates that most of the effects found were tannin-related, while the few residual effects may also have been the result of additional differences in the chemical composition in comparison to V. unguiculata. It has to be acknowledged that the amount of PEG added (35 mg/g DM) could have been insufficient for a complete prevention of tanninrelated effects, particularly in Experiment 1 where the tannin contents in some forage mixtures were exceptionally high $(>100 \mathrm{~g} / \mathrm{kg}$ DM). However, even with very high PEG concentrations in the fermentation fluid $(10 \mathrm{mg} / \mathrm{ml})$, Muetzel and Becker (2004) still found negative effects of tannins on protein degradation. These observations suggest that PEG may not fully prevent the formation of tannin-protein complexes in vitro. It remains unclear why there were certain PEG effects on IVDMD (Experiment 1) and the proportion of UDCP (both experiments) in some of the B. humidicola- and $V$. unguiculata-based mixtures where no CT were detected.

\subsection{Comparative feeding value of shrub legumes with contrasting tannin contents (Experiment 2)}

In tropical shrub or tree legumes, the presence of tannins may reduce their suitability as forage plants considerably. Until now there is no known case of tropical legumes where tannins would, as found for temperate ones, improve the protein utilization in ruminants. Makkar (2003) supposes here differences in concentrations and activities of tannins in distinct legume groups. Identifying a tropical shrub legume which would break this scheme and allow an improved protein supply for ruminants would be a breakthrough in the mission of finding ways to cope with malnutrition in tropical livestock systems.

The tannin contents of the four different shrub legumes used in the present experiments ranged from zero in $C$. argentea to $260 \mathrm{~g} / \mathrm{kg}$ DM in $C$. calothyrsus. In all fermentation variables measured, $C$. argentea was superior to the other shrubs, and there was also no effect of PEG addition in contrast to all tanniniferous shrubs. This confirms previous results of a study comparing the addition of $C$. argentea and $C$. calothyrsus (Hess et al., 2003) to a low-quality grass, which indicated that $C$. argentea has great potential as supplement for ruminants fed low-protein grasses. Among the tanniniferous shrubs, $C$. calothyrsus and $F$. macrophylla were comparable and both were clearly inferior to L. leucocephala in most fermentation characteristics. The differences between $C$. calothyrsus and L. leucocephala can be probably best explained by the lower content of CT in leaves of L. leucocephala, but there was no such difference in CT content between L. leucocephala and F. macrophylla. Therefore, additionally to content also chemical properties (i.e. molecular weight and monomeric composition) of the CT seem to play a significant role for the inhibitory effects of tanniniferous shrub legume leaves on rumen fermentation. This confirms observations made by Barahona et al. (2003) using the same in vitro system as applied in the present study: despite similar CT contents in young leaves of L. leucocephala and F. macrophylla, IVDMD (614 g/kg DM versus $231 \mathrm{~g} / \mathrm{kg} \mathrm{DM})$ and total gas production after $144 \mathrm{~h}$ of incuba- 
tion (142 ml/g DM versus $64 \mathrm{ml} / \mathrm{g} \mathrm{DM})$ were much higher with L. leucocephala than with F. macrophylla. The favourable fermentation characteristics of L. leucocephala are also in good agreement with the observations made by McSweeney et al. (1999), who reported that L. leucocephala presented higher apparent in vitro $\mathrm{CP}$ degradability than other tanniniferous shrub legumes. Although it is likely that the differences in the fermentation characteristics of L. leucocephala and F. macrophylla are mostly related to contrasting chemical properties of the CT as mentioned by Makkar (2003), other factors such as lignin content ( $80 \mathrm{~g} / \mathrm{kg} \mathrm{DM}$ versus $67 \mathrm{~g} / \mathrm{kg}$ DM in F. macrophylla and L. leucocephala) and the content and composition of non-starch polysaccharides could also be involved (Barahona et al., 2003).

\subsection{Effects of combinations of tannin-free and tanniniferous legumes in a mixture based on grass}

Results from Experiment 2 suggest a certain difference among tanniniferous shrub legumes in their effects on in vitro ruminal fermentation when mixed with a tannin-free legume. Proportions of $1 / 3$ and $2 / 3$ in the legume mixtures sometimes remained without noticeable adverse effects and sometimes not. Only minor changes in fermentation parameters were observed, when the proportion of L. leucocephala in the legume mixture was increased up to $2 / 3$. In contrast, proportions of $1 / 3$ of the legume mixture covered by $F$. macrophylla did not affect gas production but clearly decreased IVDMD and increased in the proportion of undegraded crude protein. This was less pronounced with $C$. calothyrsus, an observation which was confirmed in Experiment 1 with the two combinations with either $1 / 3$ or $2 / 3$ legume proportion where $C$. calothyrsus made up $2 / 15$ of the total DM. The results of the contrast analysis showed for most fermentation variables also significant quadratic components additionally to the linear components of the slopes, particularly with $2 / 3$ of legume in the forage mixture. This was mainly due to the fact that at $V$. unguiculata:C. calothyrsus ratios of 4:1 the shrub legume had little impact on fermentation. Any larger inclusion of either $C$. calothyrsus (both experiments) or F. macrophylla resulted in a roughly linear decline in fermentative activity. Accordingly, Fässler and Lascano (1995) observed a linear decrease in apparent CP digestibility, when C. argentea was increasingly replaced with F. macrophylla in the diet of sheep.

\section{Conclusion}

The present study illustrated that, at low proportions (up to $2 / 9$ of forage DM of $L$. leucocephala, and 1/9 of C. calothyrsus or F. macrophylla), tanniniferous shrub legumes seem to be appropriate to replace a high-quality low-tannin legume. With higher proportions, a linear decline in the content of fermentable energy and an increase in the proportion of undegraded crude protein have to be taken into account. The clear differences among tanniniferous legumes in their suppressing action on microbial fermentation suggest that not only tannin content (less adverse effects with L. leucocephala than with $C$. calothyrsus) but also tannin properties (much less adverse effects with $L$. leucocephala than with $F$. macrophylla despite similar tannin content) were of great importance. This is particularly relevant because growing site conditions may affect CT properties and cause variations 
even within legume varieties (Hess et al., 2006). These aspects have to be clarified in further investigations focusing on the detailed chemical composition of the tannins and the factors they depend on.

\section{Acknowledgements}

This study was funded by the Swiss Centre of International Agriculture (ZIL) at ETH Zurich, Switzerland. The authors are grateful to G. Ramírez for the statistical support and to the staff of the laboratory of 'Calidad de forajes; Forajes tropicales' at CIAT in Cali, Colombia.

\section{References}

Anderson, M.S., Schultze-Kraft, R., Peters, M., Hincapie, B., Lascano, C.E., 2006. Morphological, agronomic and forage quality deversity of the Flemingia macrophylla world collection. Field Crops Res. 96, 387-406.

AOAC, 1990. Official Methods of Analysis, 15th ed. Association of Official Analytical Chemists, Arlington, VA.

Barahona, R., Lascano, C.E., Cochran, R., Morill, J., Titgemeyer, E.C., 1997. Intake, digestion, and nitrogen utilization by sheep fed tropical legumes with contrasting tannin concentration and astringency. J. Anim. Sci. 75, 1633-1640.

Barahona, R., Lascano, C.E., Narvaez, N., Owen, E., Morris, P., Theodorou, M.K., 2003. In vitro degradability of mature and immature leaves of tropical forage legumes differing in condensed tannin and non-starch polysaccharide content and composition. J. Sci. Food Agric. 83, 1256-1266.

Beuvink, J.M.W., Kogut, J., 1993. Modeling gas production kinetics of grass silages incubated with buffered ruminal fluid. J. Anim. Sci. 71, 1041-1046.

Bhatta, R., Shinde, A.K., Vaithiyanathan, S., Sankhyan, S.K., Verma, D.L., 2002. Effect of polyethylene glycol6000 on nutrient intake, digestion and growth of kids browsing Prosopis cineraria. Anim. Feed Sci. Technol. 101, 45-54.

Delgado, C., Rosegrant, M., Steinfeld, H., Ehui, S., Courois, C., 1999. Livestock to 2020: the 16 next food revolution. Food, Agriculture and the Environment Paper 28. IFPRI, 17 Washington, DC, USA.

Fässler, O.M., Lascano, C.E., 1995. The effect of mixtures of sun-dried tropical shrub legumes on intake and nitrogen balance by sheep. Trop. Grassland 29, 92-96.

Hagerman, A.E., Butler, L., 1980. Condensed tannin purification and characterization of tannin-associated proteins. J. Agric. Food Chem. 28, 947-952.

Hess, H.D., Kreuzer, M., Nösberger, J., Wenk, C., Lascano, C.E., 2002. Effect of sward attributes on legume selection by oesophageal-fistulated and non-fistulated steers grazing a tropical grass-legume pasture. Trop. Grassland 36, 227-238.

Hess, H.D., Monsalve, L.M., Lascano, C.E., Carulla, J.E., Diaz, T.E., Kreuzer, M., 2003. Supplementation of a tropical grass diet with forage legumes and Sapindus saponaria fruits: effect on in vitro ruminal nitrogen turnover and methanogenesis. Aust. J. Agric. Res. 54, 703-713.

Hess, H.D., Tiemann, T.T., Noto, F., Franzel, S., Lascano, C.E., Kreuzer, M., 2006. The effects of cultivation site on forage quality of Calliandra calothyrsus var. Patulul. Agroforestry Syst. 68, 209-220.

Hess, H.D., Valencia, F.L., Monsalve, L.M., Lascano, C.E., Kreuzer, M., 2004. Effects of tannins in Calliandra calothyrsus and supplemental molasses on ruminal fermentation in vitro. J. Anim. Feed Sci. 13 (Suppl. 1), 85-95.

Makkar, H.P.S., Blümmel, M., Becker, K., 1995a. Formation of complexes between polyvinyl pyrrolidones or polyethylene glycols and tannins, and their implication in gas production and true digestibility in in vitro techniques. Br. J. Nutr. 73, 897-913.

Makkar, H.P.S., Borowy, N.K., Becker, K., Degen, A., 1995b. Some problems in fibre determination of a tanninrich forage (Acacia saligna leaves) and their implications in in vivo studies. Anim. Feed Sci. Technol. 55, $67-76$. 
Makkar, H.P.S., 2000. Evaluation and enhancement of feeding value of tanniniferous feeds. In: Brooker, J.D. (Ed.), Tannins in Livestock and Human Nutrition: Proceedings of an International Workshop, Adelaide, Australia. ACIAR proceedings No. 92, Canberra, pp. 52-56.

Makkar, H.P.S., 2003. Effects and fate of tannins in ruminant animals, adaptation to tannins, and strategies to overcome detrimental effects of feeding tannin-rich feeds. Small Rumin. Res. 49, 241-256.

McSweeney, C.S., Palmer, B., Bunch, R., Krause, D.O., 1999. In vitro quality assessment of tannin-containing tropical shrub legumes: protein and fibre digestion. Anim. Feed Sci. Technol. 82, 227-241.

Menke, K.H., Steingass, H., 1988. Estimates of the energetic feed value obtained from chemical analyses and in vitro gas production using rumen fluid. Anim. Res. Dev. 28, 7-55.

Min, B.R., Barry, T.N., Attwood, G.T., McNabb, W.C., 2003. The effect of condensed tannins on the nutrition and health of ruminants fed fresh temperate forages: a review. Anim. Feed Sci. Technol. 106, 3-19.

Minson, D.J., 1990. Forage in Ruminant Nutrition. Academic Press, San Diego, CA, USA.

Moore, K.J., Miller, D.A., 1988. Cell wall composition and digestibility in five species of Brachiaria. Tropical Agric. 65 (4), 337-340.

Muetzel, S., Becker, K., 2004. PEG does not fully prevent the formation of tannin-protein complexes in vitro. Proc. Soc. Nutr. Physiol. 13, 128.

Noguera, R.R., Saliba, E.O., Mauricio, R.M., 2004. Comparación de modelos matemáticos para estimar parámetros de degradación de gas. Livest. Res. Rural Developm. 16 (11), http://www.cipav.org.co/lrrd/lrrd16/ 11/cont1611.htm.

Norton, B.W., 2000. The significance of tannins in tropical animal production. In: Brooker, J.D. (Ed.), Tannins in Livestock and Human Nutrition: Proceedings of an International Workshop, Adelaide, Australia. ACIAR Proceedings No. 92, Canberra, pp. 14-23.

Paterson, R.T., Karanja, G.M., Roothaert, R.L., Nyaata, O.Z., Kariuki, I.W., 1998. A review of tree fodder production and utilization within smallholder agroforestry systems in Kenya. Agroforestry Syst. 41, 181-199.

Robbins, C.T., Mole, S., Hagerman, A.E., Hanley, T.A., 1987. Role of tannins in defending plants against ruminants: Reduction in dry matter digestion. Ecology 68, 1606-1615.

Robertson, J.B., Van Soest, P.J., 1981. The detergent system of analysis. In: James, W.P.T., Theander, O. (Eds.), The Analysis of Dietary Fibre in Food. Marcel Dekker, New York, pp. 123-158.

Silanikove, N., Perevolotsky, A., Provenza, F.D., 2001. Use of tannin-binding chemicals to assay for tannins and their postingestive effects in ruminants. Anim. Feed Sci. Technol. 91, 69-81.

Terrill, T.H., Rowan, A.M., Douglas, G.B., Barry, T.N., 1992. Determination of extractable and bound condensed tannin concentrations in forage plants, protein concentrate meals and cereal grains. J. Sci. Food Agric. 58, 321-329.

Theodorou, M.K., Williams, B.A., Dhanoa, M.S., McAllen, A.B., France, J., 1994. A simple gas production method using a pressure transducer to determine the fermentation kinetics of ruminant feeds. Anim. Feed Sci. Technol. 48, 185-197.

Van Soest, P.J., Robertson, J.B., Lewis, B.A., 1991. Methods for dietary fiber, neutral detergent fiber, and nonstarch polysaccharides in relation to animal nutrition. J. Dairy Sci. 74, 3583-3597.

Waghorn, G.C., Ulyatt, M.J., John, A., Fisher, M.T., 1987. The effect of condensed tannins on the site of digestion of amino acids and other nutrients in sheep fed on Lotus corniculatus. Br. J. Nutr. 57, 115-126.

Wang, Y., Waghorn, G.C., Barry, N.T., Shelton, I.D., 1994. The effect of condensed tannins in Lotus corniculatus on plasma metabolism of methionine, cystine and inorganic sulphate by sheep. Br. J. Nutr. 72, 923-935. 